\title{
NURSING STUDENTS' PREMATURE PREGNANCY AND CONSUMPTION OF ALCOHOL
}

\author{
Martha Lucio Alvarez ${ }^{1}$
}

Lucio Alvarez M. Nursing students' premature pregnancy and consumption of alcohol. Rev Latino-am Enfermagem 2008 maio-junho; 16(especial):577-83

This qualitative descriptive research aimed to analyze pregnancy dynamics, experienced by a group of women who, at the time, were at most 19 years old, and identify the role attributed to the consumption of alcohol in such dynamics. The research was developed with a group of 20 students from the Colombia National University. Six of them were selected for in dept investigation through interviews, which were analyzed by content analysis. Based on the literature and the subjects' life history, the study examines the following categories: pregnancy, making love, maternity, being a woman, and drinking. Through these categories, was possible to identify the dynamics experienced by these women during pregnancy.

DESCRIPTORS: pregnancy; alcoholic beverages; health; students, nursing

\section{EMBARAZO PRECOZ DE ESTUDIANTES DE ENFERMERÍA Y LA INGESTA DE BEBIDAS ALCOHÓLICAS}

Esa investigación cualitativa de modalidad descriptiva tuve como propósitos describir y analizar las dinámicas presentes en el embarazo de un grupo de mujeres que para el momento contaban con una edad límite de 19 años, identificando el papel que atribuyen a la ingesta de bebidas alcohólicas en dichas dinámicas. La investigación se desarrolló con un grupo de 20 estudiantes de la Universidad Nacional de Colombia. De ellas fueran seleccionadas 6 jóvenes para la investigación en profundidad, por medio de entrevistas que han sido analizadas por el método de análisis cualitativo de contenido. El artículo analiza, basado en la literatura y en la historia de vida de los sujetos de la investigación, las categorías identificadas: embarazo, hacer el amor, ser mujer, maternidad y tomar. Por ellas es posible identificar as dinámicas involucradas en las gestaciones de las jóvenes estudiadas.

DESCRIPTORES: embarazo; bebidas alcohólicas; salud; estudiantes de enfermería

\section{GRAVIDEZ PRECOCE DE ESTUDANTES DE ENFERMAGEM E O CONSUMO DE ÁLCOOL}

Esta pesquisa qualitativa, descritiva teve como objetivo descrever e analisar as dinâmicas presentes durante a gravidez em um grupo de mulheres que na época tinham no máximo 19 anos, e identificar o papel que atribuem ao consumo de bebidas alcoólicas nessas dinâmicas. A pesquisa se desenvolveu com um grupo de 20 estudantes da Universidade Nacional da Colômbia. Dentre elas, foram selecionadas seis jovens para investigação em profundidade, por meio de entrevistas que foram analisadas pelo método de análise de conteúdo. O artigo analisa, com base na literatura e na história de vida dos sujeitos da pesquisa, as categorias: gravidez, fazer amor, ser mulher, maternidade e beber. É possível identificar, através das mesmas, as dinâmicas envolvidas nas gestações vividas pelas jovens estudadas.

DESCRITORES: gravidez; bebidas alcoólicas; saúde; estudantes de enfermagem

${ }^{1}$ RN, Faculty, National University of Colombia, Bogota 


\section{INTRODUCTION}

In 2000, statistics from Colombia revealed that $15 \%$ of 15-19 year-old adolescents were already mothers and $4 \%$ were carrying their first child, totaling $19 \%{ }^{(1)}$.

According to a study carried out in 2003 at Colombia National University, the country invested over 1.2 billion pesos in adolescent pregnancy cases, an amount corresponding to mother and child treatment costs, and social impoverishment due to one of the spouses dropping out of school, affecting that person's productive life. This study reports that a million babies and around 70,000 teenage mothers die each year in developing countries due to premature motherhood ${ }^{(2)}$.

The student medical service of Colombia National University, in turn, informs that 221 students under 19 years old had been treated in prenatal control in 2003, a figure that does not fully represent reality because, every time the university requests affiliation to any of the EPS - Health Promoting Entity - or to SISBEN - Social Identification System for Social Program Beneficiaries - to enroll, these entities end up assuming many of the controls and deliveries.

Furthermore, several studies and statistical reports from Colombia reveal adolescent pregnancy as a public health concern, with implications for mothers' and children's lives, worsening the consequences of a poverty-stricken country, as quoted in a study: juvenile pregnancy is the cause and consequence of poverty. Cause because pregnancy affects educational progress in an adverse way; and consequence because poverty and lack of education raises the probability of pregnancy ${ }^{(3)}$.

Literature indicates the most easily predictable psychosocial influences of premature pregnancy: 1) dropping out of school, which in turn impairs the likelihood of a future job; 2) emotional marks left by an unwanted pregnancy or abortion, with or without complications; 3 ) affective, economic dependency, or both; 4) greater teenage mother vulnerability to prostitution and sexual exploitation, as well as to sexually transmitted diseases ${ }^{(3-5)}$.

Education institutions and families are the areas that most strongly affect this issue ${ }^{(4,6)}$. Studies on teenage fertility indicate a key role of family in teenage reproductive behavior. Although Colombia's Ministry of Education decreed sexual education as compulsory in 1993, the effect that sexual education offered in schools has had over teenagers' behavior is limited ${ }^{(6)}$.
At university, contact with young female university students reveals their lack of knowledge about reproductive behavior and permits checking for premature pregnancy and drug use, especially alcoholic beverages. Talks with students and a study in which a large percentage of Colombian university students acknowledge sexual intercourse under influence ${ }^{(7)}$ indicate a likely association between these issues.

To contribute to a further understanding of the processes involved in premature pregnancy in a group of nursing students, this research aims to unveil the context of pregnancy and check whether it is related to alcohol consumption, from the protagonists' perspective.

\section{METHODOLOGY}

From the perspective of pregnant adolescents, this study aimed to identify events related to this experience through a descriptive qualitative research. This type of research has a broad focus, looking at human relations and actions in the universe of their meanings $^{(8)}$ and its interest is to grasp the dynamics experienced by nursing students who had a premature pregnancy. A semi-structured interview was used for data collection.

After being approved by the Nursing Faculty Research Committee of Colombia National University, the research was carried out with this university's nursing students, from late 2005 until mid 2006.

When selecting subjects, in the four initial terms of the nursing major program, an oral survey was performed to identify students who had been mothers or had been pregnant up to the maximum age of 19. After being identified, 20 people agreed to participate in the research through a free and informed consent term and then data were collected about the students' socioeconomic profile. The individual interviews were done later. Only six students agreed to participate. The present paper relies on the data obtained from these six women.

With the recorded, transcribed, proofread interviews, the goal was to find the irregularities and differences, with a view to grouping the data. The qualitative analysis method was used in the process of constructing a synthesis, establishing relations, coding and classifying and categorizing data ${ }^{(8)}$. After the manifested and latent contents of the interviews had been analyzed, they were sorted out and interpreted in contrast with the theoretical sample. 


\section{RESULTS AND DISCUSSION}

The analysis was carried out according to the categories emerged from the interviews: pregnancy; motherhood; love-making; female being and drinking. These categories permit understanding the meanings they attribute to their premature pregnancy experience.

Pregnancy

The relationships between fiancées or couples were not the sexual intercourses that led to the protagonists' pregnancy; the main causes were casual one-night stands, marked by sexual attraction and urgency $^{(9)}$. This can be inferred from statements like: mom has only gone to the market... say, in our case, if he had gone for condoms, we wouldn't have had time, from starters, we don't have it at hand.

A study on pregnancy in adolescence identifies three manners to get pregnant without planning: the sudden, the premature and the residual ${ }^{(9)}$. The characteristics of the pregnancy cases the study participants experienced can be called "sudden", as the subjects did not have a stable relationship with their partner and, for three of them, it was the first sexual experience. All interviewed students report that, at the moment of conception, they were getting over the loss of someone they coincidentally call the love of my life, with whom they wished to have a baby.

The first important aspects revealed by the reports were the difficulties and the malaise that surrounds their lives since they got the premature, unwanted pregnancy. An affective background accompanies the narrations, most of the times painful and sad, and other times with connotations of insecurity and grudge. Expressions like what will I do, my life, my studies? or I've ruined my life and it's your son, see what you'll do to him, formulated by a relative, exemplifies the hue of the process. Expressions like my freedom is over explain the feelings about the hard process that pregnancy has been, as though it were a burden.

The unwanted pregnancies are not planned and relate to denials and conflicts. The likelihood of abortion is shown in the reports, openly or as a shadow, generating feelings of guilt. The six students reveal the manifested or hidden intent to have an abortion. In general, this possibility is discharged/dismissed when they recognize pregnancy itself and decide to communicate the situation to the sexual partner, relatives and/or friends.
A student reports an abortion after a previous pregnancy from a relationship with a married man, when she was 15 . On the occasion of the other pregnancy and due to a dream, the student expresses guilt and error for having interrupted gestation: I took the decision of having my baby the day I fell asleep and dreamed of a child telling me I had killed it.

Guilt feelings also relate to the presence of a child outside a formal partner relationship, which causes other aspects of their intimate lives to become evident; without the evidence, the "sin" - active sexual life outside a formal relationship - is a mere suspicion. Based on the protagonists' reports, it is all about a sexual life that violates social rules and, thus, it is as though she deserved some punishment, which would be represented by the mentioned guilt, solitude and family conflict. This situation can only be overcome by recognizing the meanings pregnancy itself has for them. They are assumed in a healthy way and contribute positively to children's education. Conversely, the harmful, weak patterns of education, that reproduce grudge, guilt and a permanent sensation of being unwanted will be perpetuated.

One related aspect to be taken into account is that pregnancy is regarded as a biological and physiologically normal condition in any woman, in distinct cultures. However, societies determine the suitable moments to live this condition and attempt (or should try) to prepare their members for this experience. In contemporary urban-industrial societies, there is some distancing between the biologically fertile-looking appearance, mental and social skills. The latter appear at a later stage and have not received proper attention from society (6,911). In this context, teenagers who "get pregnant " push the limits, as they are living a step in life which is socially designed as the time when young women have to get ready, physically and psychologically, and also intellectually and socially, to be an apt adult to start their own family and be liable for it.

Motherhood

Their awareness of motherhood relates to the sociocultural role of women, evidenced by self-care during pregnancy, and eventually by childcare: motherhood is a beautiful process, because you know that you have something of yourself inside you... For the investigated women, pregnancy care began as soon as motherhood was no longer hidden: in the first four months, I led the same 
life I had been leading before. But after I told her, pregnancy became awesome because I was able to live it to the full. In other words, there was acceptation and my son became my sunshine, my life.

Even so, all participants report important affective consequences of motherhood, explained mainly by feelings of insecurity and solitude: they would never accompany me to the doctor, I felt alone. Four of them report financial problems and point out that they relied on parents' support, which in some cases is related to submission.

Bringing up a child leads to difficulties and feelings of solitude for these inexperienced mothers; the presence of the sexual partner is reported as nearly inexistent. It is limited to some specific aspects: [name] he came with a pound of meat: 'take it to cook. A student only got her partner's financial support after a fatherhood claim.

Having a child and becoming liable for the education turns out to be a challenge for them, even though they redefine their projects in the process: everybody would tell me I wouldn't make it... Contradictory feelings express the difficulties to accept the changes in life that occurred after motherhood: I carry many crosses with the birth of... I'm so lonely and, just like my son is my reason to live, he's also the reason why things have changed so. Life projects, the ideals, goals for the person to feel realized have to change as a result of pregnancy and motherhood. They report frustration: I put off the semester, I dedicated the first six months to [child's name]... it was obviously extremely stressing to me, because I was used to always studying, I mean, I had never quit and the past six months have been scaring to me.

The interviews evidence the importance of family support, mainly from mothers. Without this support, the students feel exposed to all sorts of difficulties. Research emphasizes that a vicious circle is formed around pregnancy and the poverty generated by the lack of - economic, family, educational - means they experience $e^{(2-3,6,9)}$, a situation that is shown in the present work every time the families chose to trust their daughters and reach out to them, supporting them along with their children. Studies on the need to accompany adolescents confirm the present research results: family support is fundamental to overcome the crisis, keep on studying and take care of the baby $(2-3,6,9)$.

Making love

The reports show the understanding of sexuality reduced to intercourse, referred to as making love. This reduced sexuality understanding reflects common sex representation features among teenagers, as observed in literature ${ }^{(6)}$.

Sexual satisfaction, for the study participants, is related to feeling good or bad at the moment of the intercourse, and this feeling is associated with the existence or absence of affection between the couple. The presence of dissatisfaction, in turn, according four protagonists' reports, is associated to physical or psychological maltreatment.

Self-esteem alterations, as well as pressure coming from varied sources (sexual partner, peers, relatives) are based on the first sexual intercourse, which all participants experienced negatively. One of them says: he was one of the first who told me I was beautiful. Another one recalls: on this day he treated me well, but it was terrible later.

The sexual intercourse that originated pregnancy was a fortuitous fact, which sought to fulfill affective needs in sexual contact. All of them aspire to the ideal of love ${ }^{(5,9-10)}$, lived as failure in previous experiences. In this sense, this research agrees with the results found by a study on pregnancy among teenagers, which points out a connection between love and sexual attraction, marked by urgency ${ }^{(9)}$.

The data evidence an unorganized and incomplete informal sexual knowledge. In general, it is acquired from house cleaners, first sexual partner, young relatives and peers of the same age. No matter the extent to which sexual education has complied with compulsory subjects since 1993, when students receive it, many have already had the first sexual intercourse. This guidance, given by instructors, is also considered far from reality and unpleasant.

Most participants inform that their mother told them about their physiological development, nothing more than that. If the information about physiological changes is given by their mothers, the same does not apply to sexual education, a silenced theme that is lived as a taboo: my mom has never told me that. None of the mothers noticed their daughters' pregnancy before six months.

They receive and evaluate knowledge about family planning and sexual education from partners and adults. They acknowledge a lack of information and that they mix little knowledge with popular beliefs: there wasn't any understanding of making it safe all the times because, despite the time, we had been together a few times. Another participant says: I didn't think of that. Actually, I didn't think of safety, neither did I think this would happen to me, because it was my first time. 
In the six women's story, events are repeated in the families, such as premature pregnancy, single mothers among relatives, lack of information about sexuality and family planning, maltreatment in partner relationship, female submission to men. The importance of the family and mainly the mother at the start of teenage sexual activity, along with education they may receive at school, is recognized in studies, which equally acknowledge that history tends to repeat itself from generation to generation and does not learn from its past ${ }^{(5-6)}$.

The confusions these students are exposed to through the presence of an unplanned, unwanted pregnancy, and the negative impact on their life project, turn into emotional risk of mental suffering. Feelings of frustration and failure are constant and may lead to a lonely life. However, at the level of aspirations, life with a partner is essential.

Pondering over teenage pregnancy also leads to the need to see women as subjects with sexual, reproductive and other rights ${ }^{(5,11)}$. Considering development inequalities in Colombia, it is fundamental to prove that the surveyed teenagers have little knowledge of these rights and how to claim them. The reports evidence that this unawareness interfered in the participants' pregnancy.

Being a woman

For all the protagonists, being a woman is associated with the fear of depending on a man or of being treated as a maid, serve the man, children, being a mother: mom has to cook... my dad would arrive and ask: is lunch ready yet?, and would get angry if he wasn't served right away. The reports indicate that gender relations, fundamental to define one's personal identity, results in a submissive identity. Nevertheless, cultural gender patterns are regarded as unfair and cause tension: being obliged to be a housewife has become so painful.

Discussing the issue of what it means to be a woman leads to a reconsideration of the distinction between sex, biological status and gender, social status, pointing out that the two aspects affect the people's body, because "each body is historically built according to dreams and apprehension of its time and culture $^{\prime(12)}$. Gender is a social, historical construction of subjects as female and male, transmitted through socialization $^{(4,13)}$

Regarding gender identity, all participants have female submission models in their families, but all of them value and project the idea of being an economically independent woman on their lives. The gender identity construction process, which these women experienced contradictorily and painfully, is associated with the relations society attributes to life from the start. In the construction and cultural transmission of these relations, what the adults surrounding these young beings say and do is very important, as they are in charge of giving the examples that signal the way accepted by society $^{(4,11)}$.

Motherhood, in this context, is crucial at the moment of identification as a woman. However, there is a two-way simultaneous interface. On one side, it distinguishes and empowers women before men. On the other, it slaves women, which is why they feel doomed to solitude or in search of a partner relationship with independence.

Other aspects also attract attention in the students' reports, such as the constant presence of love disillusions, or couples that don't match women's sexual expectations, either because of violence or dysfunction. However, these facts are not only kept silent, but also faced through submissive or indecent attitudes that lead to clearly risky conduct, damaging their own integrity.

In view of female gender identity ${ }^{(4-5)}$, it can be noticed that the so-desired equality between men and women, though present in these females' mind as aspiration, is too distant from daily reality and effective sexual practices, as a teenage fertility study warned $^{(6)}$.

Part of gender inequality is represented by the absence of fatherhood. Except for two fathers who occasionally visit their children, the biological fathers are present to bring up boys, while others contribute exclusively at the economic level, an aspect described in literature ${ }^{(14)}$.

Drinking

Out of the six thoroughly studied females, three show the influence of alcoholic beverages at the moment of the sexual intercourse that caused the pregnancy and three do not.

The three females who relate premature pregnancy with alcohol consumption belong to distinct socioeconomical layers. All of them were born in Bogotá. Two had a father of rural origin. Parents' educational level ranges from incomplete primary school to finished high school. One of them got 
pregnant for the first time when she was 15, causing great disillusion and malaise; and agaom at the age of 16 - after a love disillusion, she adopted promiscuous behavior, resulting in pregnancy; the third pregnancy occurred when she was 18 . She got pregnant as a result of a relationship with a friend. Her reports reveal the influence of alcohol consumption at the moment of the pregnancy: then we were drinking, drinking a lot... I blanked out; I remember standing up, getting dressed and leaving, and that is what happened.

Their experiences are marked by personal lost and found, but that is related to the fact of alcohol consumption having impaired the recognition of a dangerous situation. The three of them lived in a setting prone to parties and they state, in their life stories, circumstances prone to vulnerability, such as the absence of father-mother authority, affective needs and easy access to alcohol, which are identified as factors that predispose to alcohol consumption ${ }^{(15)}$.

Regarding factors that predispose to alcohol consumption, this paper does not strictly address the epidemiological risk factor, but looks at the habits, customs, dispositions present in the family core or in the first support network the subject creates. They are events one is not aware of, only experienced, without questioning, and taken little by little until total absorption, with great repercussion on the attitudes of the developing subject. In the reports of the three females who relate premature pregnancy with alcohol consumption, the following factors stand out: 1) Living with consumers; 2) Alcoholic beverage permissiveness; 3) Defective father-mother authority; 4) affective voids; 5) Negative relative communication; 6) Conflicting interpersonal relationships with family members; 7) Transmission of inequality value between female and male gender.

Accepting that human beings learn, above all, by means of observation and imitation, rather than normative discourse ${ }^{(16)}$, one is able to understand the importance of daily practices in the transmission of values and models of behavior. Studies emphasize the family dynamics problems: drinking parents' behavior, alcohol consumption acceptance, parents' distance and socioeconomical status as risk factors for teenage alcohol abuse ${ }^{(15)}$.

Besides the influence of the family dynamics, individual predispositions to alcohol consumption are considered, particularly vulnerability during adolescence. Due to the psychosocial maturing process teenagers are subject to, they still cannot clearly recognize the likely consequences of their acts (17). Another important aspect is related to personality type and its own traits, which match the forming process in which the person develops susceptibility to maintain a fragile self-esteem. This condition is present in the analyzed life stories.

Sociocultural factors, which predispose to alcohol consumption, are part ofthe people's setting. In this group, it is evident that the women have easy access to alcoholic beverages in the places they frequent; Likewise, their conducts show cultural patterns that lure citizens into the consumption of alcoholic beverages(paradoxically, in Colombia, a percentage of beverage and cigarette sales is transferred to support health and sports).

One can also detect protective factors in the life stories that so far have prevented their protagonists from drowning themselves in alcohol or maintaining a promiscuity pattern with the risk of sexually transmitted diseases, including: 1) Seeing the child as affection-giving; 2) Good academic performance; 3) High educational background.

A statistical study carried out by the Unidade Coordenadora de Prevenção Integral (UCPI) reports that about $70 \%$ of university students in Bogotá consumed alcoholic beverages, especially in the first terms; $30 \%$ of them acknowledged having had unplanned sexual intercourse under influence(7). However, according to the characteristics of these records, this does not refer to the circumstances that surround such relations and the likely implications of an unplanned pregnancy.

For all of this, when the shot arises in teenage bedrooms, its consequences might be sinister. Its effects over people soberness don't allow proper events control. The guayabo - term that defines both the hangover after a binge, as a particular sadness state, characteristic of waking up after a night out, may last for life.

\section{FINALREMARKS}

It has been seen in the reported life stories how the sex taboo is formed, the way the girl is taught that there are aspects in life that are exclusively feminine and that they shouldn't be shared with men. This generates couple communication after effects concerning sexual satisfaction and family planning 
methods, or that prevent them from standing for their rights. This indicates the sociocultural heritage importance on the understanding females have about gender: what she should and shouldn't be, what she can or can't say, patterns that are transmitted throughout generations in the processes of women's sexual and reproductive development education.

Sexuality, simplified as coitus in the reports, is experienced as a form of frustration and lack of affection. However, experienced negatively, it reveals and results in self-esteem alterations.

The analyzed teenage gestations were experienced as a burden, an obstacle, and have radically changed their life projects. Family or couple support, when present, show great importance during pregnancy and motherhood.

Among the six students, three report the influence of alcoholic beverage consumption over the sexual intercourse that generated pregnancy. Even though the limited number of interviewees does not allow generalizations, it is possible to establish a connection between alcohol consumption and risky sexual behavior in their life reports.

\section{ACKNOWLEDGEMENTS}

Acknowledgements to the Inter-American Drug Abuse Control Commission/CICAD of the SubSecretary of Multidimensional Security at the Organization of American States/OAS, the Brazilian Anti-Drugs Secretary/SENAD, faculty members at the University of São Paulo at Ribeirão Preto College of Nursing, WHO Collaborating Centre for Nursing Research Development, Brazil, to the population who participated in the studies and to the representatives from eight Latin-American countries who participated in the I and II On-Line Specialization Program for Research Capacity-Building on the Drugs Phenomenon-PREINVEST, offered in 2005/2006 by the University of São Paulo at Ribeirão Preto College of Nursing, as a distance education course.

\section{REFERENCES}

1. Encuesta Nacional de Demografía y Salud. Colombia: PROFAMILIA; 2000.

2. Parada AJ. El embarazo adolescente le cuesta al país. UN Periódico 2005 Marzo; 20:8-9.

3. Tenorio MC. Las Mujeres no Nacen, se Hacen. Modelos Culturales de Mujer entre Adolescentes de Sectores Populares. Colombia: Universidad del Valle, Colciencias; 2002.

4. Londoño A. Relatos sobre adolescencia y construcción de las identidades de género. Documentos conceptuales. Proyecto educación en salud sexual y reproductiva de jóvenes y para jóvenes. México: MEN-UNPFA; 2001.

5. Checa S, organizadora. Género, sexualidad y derechos reproductivos en la adolescencia. Buenos Aires: Paidós; 2003. 6. Flórez CE, Vargas E, Henao J, Gonzáles C, Soto V, Kassem D. Fecundidad Adolescente en Colombia: Incidencia, Tendencias y Determinantes. Un Enfoque de Historia de Vida. Colombia: CEDE Universidad de los Andes; 2004.

7. Unidad Coordinadora de Prevención Integral (UCPI). Factores asociados al uso de drogas en la población universitaria de Bogotá. Documento final. Bogotá: Alcaldía Mayor; 2003.

8. Triviños ANS. Introdução à Pesquisa em Ciências Sociais. A Pesquisa Qualitativa em Educação. São Paulo: Atlas; 1987. 9. De La Cuesta C. Tomarse el Amor en Serio: Contexto del
Embarazo en la Adolescencia. Colombia: Universidad de Antioquia; 2002.

10. Kristeva J. Historias de amor. México: Siglo Veintiuno Editores; 1993.

11. Hawkes G. A Sociology of Sex and Sexuality. Buckingham/ Philadelphia: Open University Press; 1996.

12. Vieira EM. A Medicalização do Corpo Feminino. Rio de Janeiro: Fiocruz; 2002.

13. Lamas M. Usos, dificultades y posibilidades de la categoría género. In: Lamas $M$, organizadora. El género: la construcción cultural de la diferencia sexual. México: UNAM. PUEG; 1997.

14. Paván G. La maternidad adolescente desde la perspectiva de sus protagonistas. Cuadernos de Postgrado 29. Venezuela: Facultad de Humanidades y Educación, Universidad Central; 2001.

15. Ruiz MR, Andrade D. La familia y los factores de riesgo relacionados con el consumo de alcohol y tabaco en los niños y adolescentes (Guayaquil-Equador). Rev Latino-am Enfermagem 2005 setembro-outubro; 13 (número especial):813-8.

16. Bandura A. Social foundations of thought and action: a social cognitive theory. Englewood Cliffs( NJ): Prentice; 1986. 17. Reguillo R. Emergencia de culturas juveniles. Estrategias del desencanto. Bogotá, Colombia: Grupo Editorial Norma; 2000. 